\title{
Introduction
}

\section{Religion Impacting the Concept of Law}

\author{
Stefan Hammer \\ Professor, Department of Legal Philosophy, University of Vienna, \\ Vienna, Austria \\ stefan.hammer@univie.ac.at
}

\begin{abstract}
The issue reflects on concepts of law determined or impacted by various currents of Abrahamitic religious traditions. Major alternative approaches regarding the status of revelation as a source of law are being addressed. Two basic types of religious approach can be distinguished: one embracing the idea of divine revelation containing prescriptions which are to be connected to and implemented in human legal and political reasoning, and another one absconding the divine from earthly political and legal paradigms in order to permeate them with relativizing spirituality. The various contributions explore the historical development of relevant strands of religious thought as well as the way in which they articulate themselves in the present-day diversity of a secularized and globalized environment.
\end{abstract}

\section{Keywords}

religion - revelation - law - secularity - apophatism

The contributions collected in this issue touch upon a vast range of themes revolving around the attitude of religions towards law. Given the limited number of articles in relation to the breadth of the subject, it seems appropriate 
to indicate what may and what should not be expected: First, the collected articles provide no overview of the different types of religion-state relations adopted in various countries, but they start from the religious perspective and trace its impact on the non-religious legal environment. Second, the issue is limited to religions attributed to the "Abrahamitic" tradition and thus referring to some pivotal point in divine revelation. Third, the perspectives presented here do not exhaust the varieties that can be found within the respective religious traditions, and they are not necessarily representative of the mainstream orientations within these traditions. And finally, taken together, the collection of articles does not focus on empirical aspects of social or political developments, although such instances may be addressed occasionally. It is rather meant as a contribution to the history of ideas and its reflection under the intellectual settings of modernity and globalization.

Is something like "religious law" conceivable? If it is presupposed that human behaviour can be subject to transcendent measurement, a difference between concealed transcendence and immanence accessible to human comprehension is implicit from the outset. Religious traditions addressing this point display various alternatives on how to conceive of the difference between transcendence and immanence with regard to the concept of law: Can law as such be understood as emanating from a divine source at all? Such an assumption implies a critical difference within the concept of law itself, as human comprehension and implementation of what is considered to be the divine law is constantly to be measured against the transcendent corrective of divine will, whereby the latter again constantly escapes full human comprehension. Or else, does the insurmountable remoteness of divine will exempt the religious sphere altogether from everything that can be considered as law governing human (inter)action? Obviously, the variety of religious approaches exemplified as basic alternatives in Part I does not simply inform the relationship between religion and law, but also and more fundamentally the concept of law itself. Seen from a secular side which is inherent to the concept of law as such, those various religious approaches amount to examples within a wide range of "multiple secularities" developed in different historical and cultural contexts. ${ }^{1}$

As far as the possibility of divine commands for human conduct, and hence of religious law (in the broadest sense), is affirmed, as is the case in Talmudic

1 Burchardt/Wohlrab-Sahr/Middell, Multiple Secularities Beyond the West. 
law, this affirmation implies a kind of secular momentum within religion itself. As Hanina Ben Menahem points out, it manifests itself in the presupposed requirement of human acceptance of divine revelation. As a condition of the binding force of God's commands, this requirement not only alters the concept of revelation to a communicative relationship but also confers an element of flexibility unto the legal practice of implementing the divine will: As the modality in which the divine will is binding upon humans takes into account imperfect human understanding from the outset, it translates into rules that may call for derogations in particular cases in which judicial reasoning considers the divine will to be better realized in that way. When looking at modern secular law, which shows similar features of judicial discretion in the application of rules, Ben Menahem identifies considerable affinities with religious law, which may in reverse suggest a "spiritualized" perception of secular law - a motif to which we will return at the end.

In addition to the insight that human comprehension necessarily falls short of the perfection of divine justice, Augustinian approaches also consider law to be inescapably contaminated with human failure and sin. This point of departure represents a somewhat opposite strand of theological thought according to which human law and legal practice, instead of being determined by divine commands, are rather being exiled from the purview of the divine realm. At best, divine revelation takes on a critical function, constantly reminding humans of the contamination of their earthly action with evil.

Augustinian skepticism towards law has found a radical expression in Lutheran Protestantism. As elaborated by Friedemann Barniske, the Lutheran view has restricted revelation to the historical encounter of humanity with the person of Jesus as incarnation of God. Religious prescriptions can, if at all, be regarded as an aspect of divine revelation only insofar as they negatively point towards salvation, which is understood as liberation from law through the grace of believing in Jesus Christ. Thus, reflecting the well-known Lutheran doctrine of justification, questions regarding prescriptive standards for human behaviour are externalized from the sphere of faith, as they are viewed as essentially pertaining to the sphere of earthly human deficiency. By ruling out any option of resorting to non-religious conceptions of natural law as well, this influential variant of Protestantism has left the pious conscience without any impactful criteria for discerning blatant earthly injustice, thus amounting to a kind of positivist indifference even vis-à-vis the Nazi regime.

Interestingly, the post-war turn of Lutheran Protestantism towards a more evaluative appreciation of secular law in a society on its way to democratization, as described by Barniske, corresponds to the revision of secular legal positivism and the turn towards natural law, most prominently expressed by 
Gustav Radbruch in his seminal article of $1946,{ }^{2}$ in which he demands suprapositive minimal standards of justice to be integrated into the concept of law. From a religious perspective as well, such a turn would indeed presuppose the recognition of the relevance of natural law principles as a condition for the legitimacy of (religious and secular) human law.

But can the idea of revealed divine law, transcending human reason, be upheld side by side with natural law and its rational modality? Famously, Thomas Aquinas has tried to reconcile voluntarist and intellectualist moments in human comprehension of justice, so that divine and natural justice may complement and interpret each other. This kind of approach has not only permeated the tradition of Christian thought but, as Mohammad Rasekh shows with a focus on Shiite tradition, has also played a central role within Islamic theories on the foundations of law. Indeed, a broad line of Islamic thinking, comparable to the Thomasian approach which is still present in today's Ecclesiastical law of the Roman Catholic Church, has produced ramifications in diverse legal theologies which eventually merge with secular legal concepts and principles developed independently from Islamic religious sources. But as Rasekh argues, maintaining the supra-rational nature of a divine source of commands on the one side, while at the same time presupposing their intelligibility by human reason and their applicability in the context of earthly legal reasoning on the other, amounts to a contradiction that cannot be resolved as long as the understanding of revelation as a source of law is being upheld. The question rather calls for a reconsideration of the nature and function of divine revelation as such and thus turns out as pertaining to the philosophy of religion rather than to religion itself.

Thus, alluding to the Kantian alternative of whether religion should be related to the question of "what am I to do?" or rather to something that transcends prescriptions for human behaviour (in the Kantian view amounting to the question of "what can I hope for?"), we can roughly distinguish between two basic types of religious approach: one embracing the idea of divine prescriptions to be connected to and implemented in human legal and political reasoning, and another one absconding the divine from earthly political and legal paradigms in order to permeate them with relativizing spirituality beyond human reason.

2 Radbruch, Statutory Lawlessness and Supra-statutory Law. The German title from 1946 reads: "Gesetzliches Unrecht und übergesetzliches Recht“. 


\section{Religion Assimilating the Law}

Part II comprises contributions addressing attempts to unfold religious law through human reason right from the outset. Such a point of departure allows religious legal reasoning to develop in a way that can connect with the historical transformation of normative concepts and principles in the respective social and cultural environment.

In present-day Canon law of the Roman Catholic Church, Thomas Aquinas' conciliative integration of divine (revealed) law and natural law in an encompassing doctrinal system is clearly recognizable. As compared to Protestant legal skepticism, the Catholic Church understands itself not only as a spiritual but also as a legal community. By virtue of the Church's self-understanding as a spiritual community of believers, Canon law specifies certain duties to believe, which, according to Burkhard J. Berkmann's analysis, have yet to be taken as moral, not as legal duties, thereby confirming a distinction that has become central in modern secular law. Nevertheless, following Berkmann, moral obligations (and their violation) entail legal consequences. Thus, religious law faces frictions with the demands of modern secular law that protects freedom of belief also against restrictions by third parties, such as religious communities. This points to a more fundamental ambivalence: Based on its emphatic recognition of natural law, the Catholic Church acts as a global human rights defender with a special emphasis on religious freedom all over the world. On the other hand, divine law qualifies the way in which the Church can recognize religious freedom for its own members. As a spiritual community united by a common belief in what is regarded as religious truth, the Church tends to regard itself as the only legitimate religious community, whereas as a legal community exercising the universally valid religious freedom, it recognizes itself as one particular religious community among others and insofar joins the perspective of secular law.

Opening religious precepts towards the extra-religious contexts may result in a modernizing transformation of religious legal concepts. That is what Ghazaleh Faridzadeh elaborates by referring to Koselleck's construction of conceptual history, according to which concepts originally informed by past experience may, in the course of modernization processes, take up meanings informed by future expectations. Thus, modernization processes in the societal environment profoundly alter the way in which law's regulating tasks are being perceived. In the Islamic context, this approach may serve as a strong case against a sort of "hermeneutical inversion" which can frequently be detected in Salafist/Wahhabist approaches: Against the hermeneutical critique according 
to which freezing the literal meaning of religious prescriptions while ignoring the historical changes in the societal environment would block the permanent implementation of the normative objectives or "messages" of such prescriptions, Salafist/Wahhabist approaches seem to turn this argument upside down when they insist on preserving societal conditions to which those prescriptions were originally directed in order to preserve the latter's original objectives. But the impact of Koselleck's approach goes beyond an ongoing, yet merely reactive adaptation of religio-legal precepts to everchanging socio-political circumstances. The turn in legal concepts from past experiences towards future expectations unleashes the vision also of legal practice taking part in actively designing future society, thereby reflecting the notion of "Weltentwurf" which is characteristic of modernity's approach towards human historicity.

Opening religious law towards modernity may also manifest itself in the adoption of religious legal reasoning and its adjustment to modern legal standards by a secular judiciary. Wiebke Greeff recapitulates some achievements in the fundamental rights jurisprudence of the Egyptian Supreme Court in the 1990s. The Court has engaged in creative use of traditional instruments of Islamic legal reasoning, based on the explicit constitutional incorporation of Sharia Law as a source of law of the Egyptian legal system. As if acting as Islamic legal scholars, the judges have occasionally arrived at modifying Islamic legal precepts so as to make them compatible with the Human Rights standards that had also been incorporated in Egyptian constitutional law.

As compared to Catholic Canon Law, Sunni Islamic Law does not seem primarily concerned with constituting a legally organized religious community. This is reflected in the fact that a direct counterpart to the hierarchical structure of the Catholic Church is lacking. The focus on rules of behaviour rather than on organizational rules possibly also facilitates tendencies to detach Islamic Law from the assumption of legally embodying a spiritual community tightly united by a common inner belief of its members. Rather, apart from systematically unfolding duties against God, unfolding a reasonable set of prescriptions for a just living together among humans has been regarded as a paramount task. When awareness of the rootedness of the legal system in a particular revelational source becomes more remote, this allows for taking up precepts for living together emerging from multiple cultural identities as well as from a globalized society. This is what Rüdiger Lohlker elaborates on the example of Indonesian developments in Islamic Law. Pointing at assertions according to which reason is to take explicit precedence over revelation in the system of the sources of law, and at other voices that express the need to bridge the boundaries between Muslim and non-Muslim jurisdictions, Lohlker's analysis leads to an integrated synopsis of indigenization and globalisation which 
both can be considered as the dialectical moments of generating something like "concrete universality".

It might appear striking that none of the contributions on Islam are devoted to what can be categorized as "fundamentalist" in present-day Islamic thought. Lohlker presents Indonesian approaches as distinguishing themselves from what they tend to dismiss as an Arabic reading of Islam. Indeed, alongside with the middle Eastern instances of progressive, reform-oriented approaches, it is the Indonesian example which is specifically meant to point at alternative readings of "Islamic Law" which could also contribute to attenuating the pervasive European obsession with "political Islam" to which Islam presently tends to be approximated.

\section{3}

\section{Religion Challenging the Law}

Part III turns towards religious conceptions that proceed from law-skepticism somewhat reminiscent of Augustinian awareness of the fallen state of humanity. This approach is complemented by an apophatic reservation regarding the ability of human reason to know God, to capture divine justice or to attain human fulfilment through rational endeavours to design earthly life and the politico-legal order of society. As the Christian Orthodox tradition considers Christian faith as the only possible remedy for these deficiencies, the Church has been assigned a relativising moral function also with respect to the temporal power and its handling of the law, without directly assuming legislative power - a feature that was meant to be institutionalized under the term of Symphonia. This appears as a decisive difference to the Western (Latin) understanding of the relationship between "spiritual" (Papal) and "temporal" (Imperial) powers, in which the two powers were conceived of as jurisdictions to be legally defined and kept apart as such. In the Orthodox understanding, religion, instead of diffusing its message through the modality of law, rather aims at diffusing a spirituality that may relativize the law. This probably also corresponds with the Orthodox tendency to open the concept of revelation from its limitation to the holy scripture or to the historical encounter of mankind with Jesus Christ towards its potential perpetuation in ramifications that may be experienced in ongoing earthly human life. The underlying apophatic approach may eventually spread beyond confessional limits and question the autonomy of purely secular paradigms which, in their turn, confine spirituality to compartmentalized spheres labelled as sacred or religious.

In mapping out the spiritual fundamentals of Symphonia, Dragan Šljivić and Neven Cvetićanin also elaborate on the related concept of Oikonomia, a 
term that can be circumscribed as religious equity in the enforcement of rules. Especially legal rules should always be applied under the apophatic awareness that nobody can claim ultimate insight into divine justice. This resonates with Ben Menahem's observations on religious considerations that justify judicial discretion regarding the application of strict rules in particular cases and thus eventually coincide with similar features in secular law.

As to the position of the Orthodox Church in systems of Symphonia, Šljivić and Cvetićanin first address the historical aspects of the institutionalization of the Orthodox Church within the political system. While claiming a monopolized non-legal, spiritual authority, critically distancing itself from temporal power, the Church nevertheless demands a legally secured position guaranteeing its autonomy as a part of the overall politico-legal order of society. Paradigmatically, this has been reflected in the Orthodox notion of "canonical territory", traditionally defined in relation to the respective state borders. With the state's legal order having embraced modernity and understanding itself as a secular, autonomous system, as in the Serbian case since the 19th century, the need for referring to the spiritual authority of the Church has vanished. Hence, the remaining political function of Orthodoxy, similar to other countries, has rather shifted towards reinforcing national identity.

By contrast, the Russian example shows a growing impact of Orthodoxy on secular legislation. Alexander Ponomariov gives an account of the Russian Orthodox Church's recent successes in "re-spiritualizing" secular law at crucial points such as the definition of marriage. In the course of its genealogy going back to the Byzantine adoption of Roman law, the concept of marriage has undergone a gradual "purification" from antique remnants of "pagan" natural law, before it has as such been implanted into Russian legislation. At bottom, the distancing from non-Christian natural law concepts in orthodox thought appears to be connected to its relativizing, moralizing understanding of the concept of human dignity, as it is reflected in Roc's relevant documents: ${ }^{3}$ Unlike its recognition in secular constitutionalism as unconditional and unforfeitable attribute of every human person, human dignity according to the Orthodox view originates in the human likeness with god and is thus more or less obfuscated in the fallen nature of humanity, so that it can be fully regained only through spiritual return or "divinization" of the human person. This perhaps best illustrates the ambivalent significance of a fundamental

3 See especially the Basic Principles of the Russian Orthodox Church's Teaching on Human Dignity, Freedom and Rights. 
spiritual skepticism towards any justificatory assertions based on self-relying human reason.

Apophatic skepticism is being traced back to its origins by Miroljub Gligorić following the philosophy of Christos Yannaras. In seeking to broaden the apophatic approach in order to mobilize it for present day social and political conditions, Yannaras situates its inception already in the pre-Christian Greek polis. This allows him to develop a critical approach towards present-day rationalism beyond religious confinements, but also to take up ideas that remind us of contemporary communitarianism, such as the neo-Aristotelian advocacy of small political communities rooted in a common ethos. Yet Yannaras also refers to early Christian spirituality as continuation and enrichment of the apophatic tradition, informed by the understanding of trinity as relation, and arrives at the conclusion that the relation between humans can never be fully grasped by instrumental, purpose-oriented rationality, which he labels as cataphatic as opposed to apophatic. In resonating with communitarian skepticism towards the workability of the liberal project of isolating rational justice from comprehensive ethical assumptions, Yannaras seeks to spiritualize the argument and to spread the critical spirit of apophatism among all ideological contexts dominated by reductionist features of cataphatic rationality.

Despite numerous questionable implications of Yannaras' philosophy which Gligorić points out, it is interesting to see how Yannaras' vision of diffused spiritual perspectives which transgress the limits of identifiable religious affiliations corresponds to increasing difficulties of modern constitutional liberalism to adequately handle the diversity of comprehensive convictions, world views and human images in a way that is compatible with ethico-religious neutrality. Irene Klissenbauer takes up relevant discussions among American constitutionalists that turn around the question of whether religious freedom can satisfy the liberal concern for equal protection of today's enhanced diversity of spiritual needs. Even if the scope of the freedoms of thought, religion or belief are open for judicial expansion, the liberal balancing of interests increasingly reveals itself as dependent on implicit assumptions on ethical life that are not unquestionably shared in highly diverse societies. This renders fundamental individual and collective interests increasingly incommensurable and thus challenges the liberal claim of devoting equal respect to the existential needs of every human being. Thus, in Yannaras' terms, the cataphatic logic of liberal constitutionalism pushes itself towards its own aporetical limits and is thus compelled to open itself towards a kind of constitutional apophatism in which freedom and autonomy as the basic principles of social and political life are constantly to be re-negotiated. 


\section{Biography}

Stefan Hammer is Professor of public law and legal philosophy at the University of Vienna. His main areas of research are comparative and European constitutional law, political philosophy, human rights and constitutionalism from an intercultural perspective. Stefan Hammer has taught at Universities in Senegal, the USA, Slovakia, France, Ethiopia, and Bhutan, and has directed international research projects in comparative constitutionalism. Since 2009, he has been engaged in interreligious dialogue conferences with Iran and Indonesia on political justice, human rights and religious pluralism. He is a member of the Research Centre "Religion and Transformation in Contemporary Society" at the University of Vienna and has been a member of the Board of Advisors of the International Development Law Organization (IDLO).

\section{Bibliography}

Basic Principles of the Russian Orthodox Church's Teaching on Human Dignity, Freedom and Rights, adopted by the Russian Orthodox Church in June 2008, http://ortho doxrights.org/documents/russian-church-freedom-and-rights (date of last access: 22.04.2021).

Burchardt, Marian/Wohlrab-Sahr, Monika/Middell, Matthias (eds.): Multiple Secularities Beyond the West. Religion and Modernity in the Global Age. Boston/Berlin/ Munich: De Gruyter 2015.

Radbruch, Gustav: Statutory Lawlessness and Supra-statutory Law (1946), translated by Bonnie Litschewski Paulson and Stanley L. Paulson, in: Oxford Journal of Legal Studies 126 (1/2006) pp. 1-11. 